\title{
Computed tomography findings of retinoblastoma patients at Cipto Mangunkusumo Hospital Jakarta
}

\author{
Dewi Asih, ${ }^{1}$ Djayadiman Gatot, ${ }^{2}$ Rita S. Sitorus ${ }^{3}$ \\ ${ }^{1}$ Department of Radiology, Faculty of Medicine, University of Indonesia, Cipto Mangunkusumo Hospital, Jakarta, Indonesia \\ 2 Department of Pediatric, Faculty of Medicine, University of Indonesia, Cipto Mangunkusumo Hospital, Jakarta, Indonesia \\ ${ }^{3}$ Department of Ophthalmology, Faculty of Medicine, University of Indonesia, Cipto Mangunkusumo Hospital, Jakarta, Indonesia
}

\begin{abstract}
Abstrak
Tujuan Karena belum ada data mengenai gambaran Tomografi Komputer (TK) pada pasien retinoblastoma (RB) di Indonesia maka tujuan penelitian ini untuk menentukan distribusi pasien dan menggambarkan temuan TK pada pasien RB di Rumah Sakit Cipto Mangunkusumo.

Metode Melakukan pemeriksaan TK dari April 2004 sampai Agustus 2007 pada 64 pasien RB baru dengan tanda klinis leukocoria pada 19 pasien, leukocoria disertai dengan penonjolan bola mata pada 41 pasien, buftalmus pada 2 pasien dan mata merah pada 2 pasien. Pemeriksaan menggunakan single slice CT dan multislice CT potongan aksial dan potongan koronal. Hasil TK dikelompokan menjadi 3 golongan: golongan I: tumor terbatas di bulbus okuli, golongan II: tumor meluas mengenai jaringan lunak orbita atau nervus optikus, dan golongan III: tumor meluas melewati orbita mencapai ruang intrakranial. Setiap golongan dievaluasi tentang adanya kalsifikasi, penyangatan kontras dan lateralisasi.

Hasil Dari 64 pasien retinoblastoma yang dievaluasi (30 anak perempuan dan 34 anak laki-laki) dengan rentang usia 3 bulan-9 tahun terdapat tumor bilateral pada 20 pasien, dan unilateral pada 44 pasien. Leukocoria ditemukan pada 19 pasien (6 pasien golongan I, dan 13 pasien golongan II). Proptosis ditemukan pada 41 pasien (27 pasien golongan II, dan 14 pasien golongan III). Pasien dengan bufthalmus dan mata merah ternyata dari hasil TK masuk golongan II. Kalsifikasi dan penyangatan terlihat pada semua golongan I (6 pasien). Pada golongan II (44 pasien) ditemukan kalsifikasi pada 41 pasien dan tidak terlihat penyangatan pada 6 pasien. Pada golongan III (14 pasien) tidak terlihat kalsifikasi pada 2 pasien, sedangkan semua pasien lainnya memperlihatkan penyangatan.

Kesimpulan Pada studi ini kalsifikasi terdapat pada 92\% kasus. Kalsifikasi bukan merupakan suatu petanda prognosis yang baik karena kalsifikasi dapat terlihat pada hampir semua kasus ekstraokular dan intrakranial. Penyangatan kontras tidak berhubungan dengan perluasan tumor ke ekstraokular. Penemuan klinis leukocoria dan belum terdapat proptosis tidak menyingkirkan adanya perluasan ke ekstraokular. Kemungkinan invasi intrakranial harus difikirkan pada pasien proptosis. Umumnya kasus RB di RSCM didiagnosis pada stadium lanjut sehingga tujuan terapi lebih untuk mempertahankan kehidupan tanpa melihat fungsi penglihatan. (Med J Indones 2009; 18: 239-43)
\end{abstract}

\begin{abstract}
Aim As data of CT findings for retinoblatoma in Indonesia is not yet available, this study aimed to determine patient distribution and to describe CT findings of RB patients at Cipto Mangunkusumo Hospital.

Methods From April 2004 to August 2007, CT scans were performed on 64 new patients of RB with clinical findings: leukocoria (19 patients), leukocoria with proptosis (41 patients), buphthalmus (2 patients) and red eyes (2 patients). The CT scan was performed using single slice CT scan and multislice CT scan with axial and coronal section. The cases were categorized into 3 groups: grade I: tumor confined to the globe, grade II: tumor extended to orbital soft tissue or involved the optic nerve, and grade III: tumor extended beyond the orbit or intracranial space. The CT features were evaluated in each group for the presence of calcification, contrast enhancement and lateralization.

Results Sixty four patients (30 females and 34 males) were evaluated. Age range: 3 months up to 9 years old; bilateral 20 patients, unilateral 44 patients. Six patients of 19 patients with clinical finding leukocoria were included in group I, and the remaining were included in group II. Twenty seven patients of 41 patients with proptotic eyes were included in group II, and the remaining were included in group III. Patients with clinical finding buphthalmus and red eyes were included in group II. All of the group I tumors (6 patients) showed calcification and enhancement. In group II (44 patients), calcification was detected in 41 patients, and there was no evidence of contrast enhancement in 6 patients. Group III (14 patients): no calcification in 2 patients, all of the tumors showed enhancement.

Conclusion Our study showed calcification in $92 \%$ of RB. Calcification was not a favorable prognostic sign, because calcification was detected in almost all of the extraocular and intracranial tumors. Tumor enhancement was not correlated with extra ocular tumor extension. The finding of leukocoria without proptosis could not exclude the presence of extraocular tumor extension. Suspicious intracranial invasion should be considered in proptotic RB patient. Most retinoblastoma cases in Indonesia are diagnosed at advanced stage, so that the objective of the therapy is life saving rather than visual salvation. (Med J Indones 2009; 18: 239-43)
\end{abstract}

Key words: leukocoria, enhancement, calcification 
Retinoblastoma(RB) is a commonintraocularmalignancy in children, the incidence in US is 1/15.000- 30.000 live birth. ${ }^{1}$ In Korea, the estimated incidence is reported as 2040/year according to Korean Central Cancer Registry. ${ }^{2}$ No exact data on the RB incidence has been reported in Indonesia. Data from Hematooncology Child Health Clinic Cipto Mangunkusumo (CM) Hospital showed that RB incidence was 163 cases in the period of 20002006, and RB is the second most common childhood malignancy after acute lymphocytic leukemia. ${ }^{3}$

Diagnosis of retinoblastoma is made based on clinical featuresandultrasonography. However, ultrasonography can not clearly show the anatomical structure posterior to a calcification, while calcification is common (about 90-95\%) in retinoblastoma. ${ }^{4-8}$

Computed tomography (CT) scanning is a method to evaluate the extraocular and intracranial extension of tumor mass, as well as the presence of tumor in the pineal body. Computed tomography sanning is the best modality to asses calcification, which is frequently not detected by Magnetic Resonance Imaging (MRI). ${ }^{4-6}$

As the majority of RB patients at CM Hospital are not wealthy patients, cost effective methods in the evaluation of tumor extension is required. Therefore, CT scan remains a modality of choice in CM Hospital.

This study aimed to determine patient distribution and to evaluate the CT findings in diagnosing retinoblastoma in CM Hospital.

\section{METHODS}

All patients, who were clinically diagnosed as having RB by pediatric ophthalmologist in Cipto Mangunkusumo hospital in the period of April 2004 to August 2007 and had been evaluated by CT scan were included in this study. The clinical findings were noted for each patient.

Modality and scanning technique: single-slice CT and multi-slice CT were used. All patients underwent orbital and cranial CT. The axial and coronal cutting in single slice CT were $1.5 \mathrm{~mm}$ and $5.0 \mathrm{~mm}$ in thickness, respectively, whereas in multi slice CT, the thickness was $1.5 \mathrm{~mm}$ and $3.0 \mathrm{~mm}$, respectively.
Sagital and coronal reconstructions were performed in multi-slice CT, and KV 100 and mAS 80 was used to decrease the radiation doses. Radiology pictures were taken before and after administration of contrast media. The outcomes were classified into 3 groups: grade I: tumor was limited to the globe (Figure 1), grade II: tumor had extended to orbital soft tissue or had invaded the optic nerve (Figure 2), grade III: tumor extended beyond the orbita to intracranial space (Figure 3)

Each group was evaluated for the presence of calcification, contrast enhancement and lateralization. For each patient the CT results were compared with clinical findings.

\section{RESULTS}

Sixty four patients (30 girls and 34 boys) were included in this study. The age was ranging from 3 months to 9 years; The affected eyes were: bilateral in 20 patients, and unilateral in 44 patients. The clinical features were leukocoria in 19 patients (30\%), leukocoria and proptotic eyes in 41 patients (64\%), buphthalmus in 2 patients (3\%), and red eyes in 2 patients (3\%). The comparison between clinical findings and grade of CT result revealed that six of the 19 patients with leukocoria had grade I, and 13 patients had grade II. Twenty seven of the 41 patients with proptotic eyes had grade II, and the remaining had grade III. Patients with buphthalmus and red eyes all had grade II.

The results of CT scanning (enhancement and calcification) in group I-III can be seen in Table 1. Calcification was found in $92 \%$ of patients. Figure 1-3 showed CT scan findings in grade I-III. The pattern of intracranial extension was 10 patients (72\%) to the optic chiasma through optic nerve, and 4 (28\%) had epidural metastasis.

Table 1. Calcification and Enhancements

\begin{tabular}{lccc}
\hline & $\begin{array}{c}\text { Number of } \\
\text { cases }\end{array}$ & Calcification & Enhancement \\
\hline Group I & $6(9 \%)$ & $6(100 \%)$ & $6(100 \%)$ \\
Group II & $44(69 \%)$ & $41(93 \%)$ & $38(86 \%)$ \\
Group III & $14(22 \%)$ & $12(86 \%)$ & $14(100 \%)$ \\
& & & \\
\hline
\end{tabular}



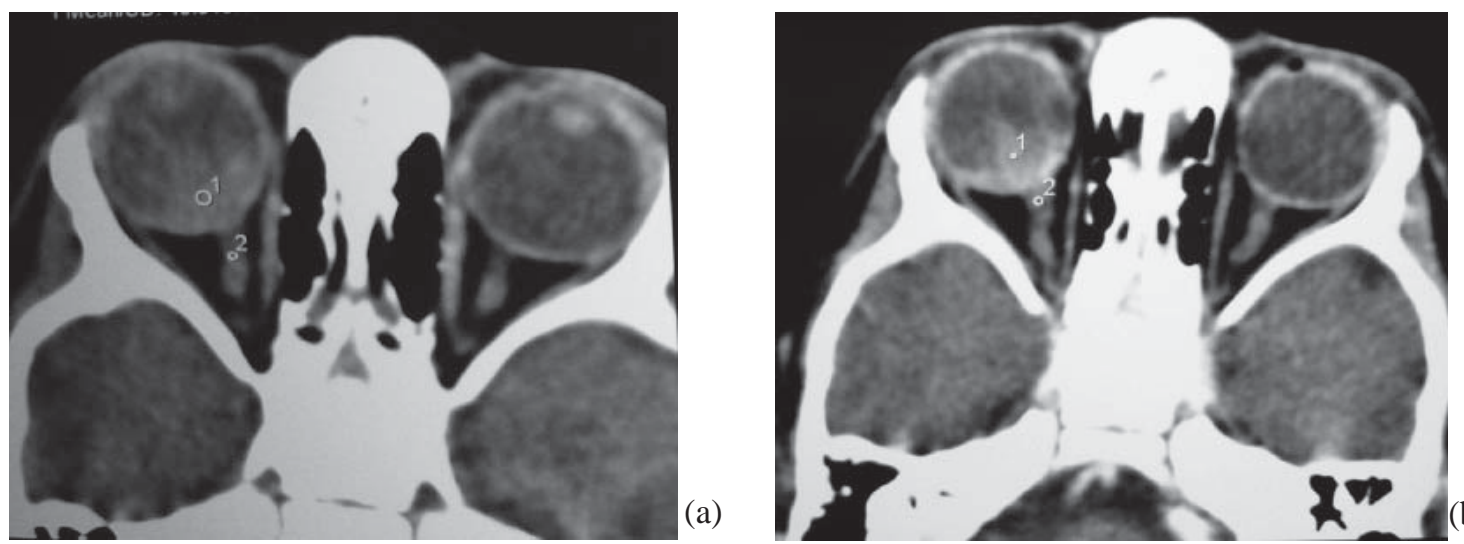

Figure 1. CT scan findings in grade I. (a) pre contrast; (b) post contrast showed enhancement

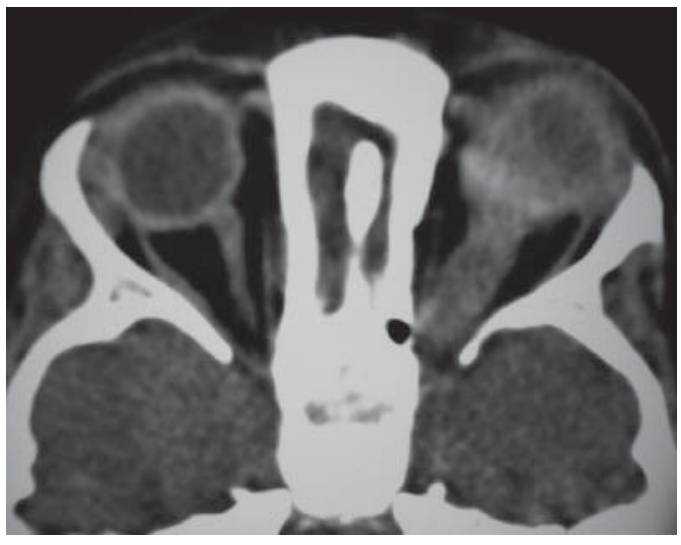

(a)

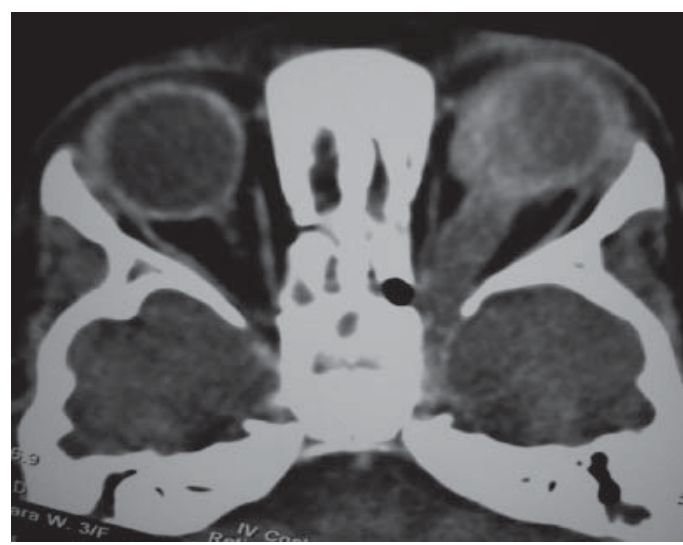

(b)
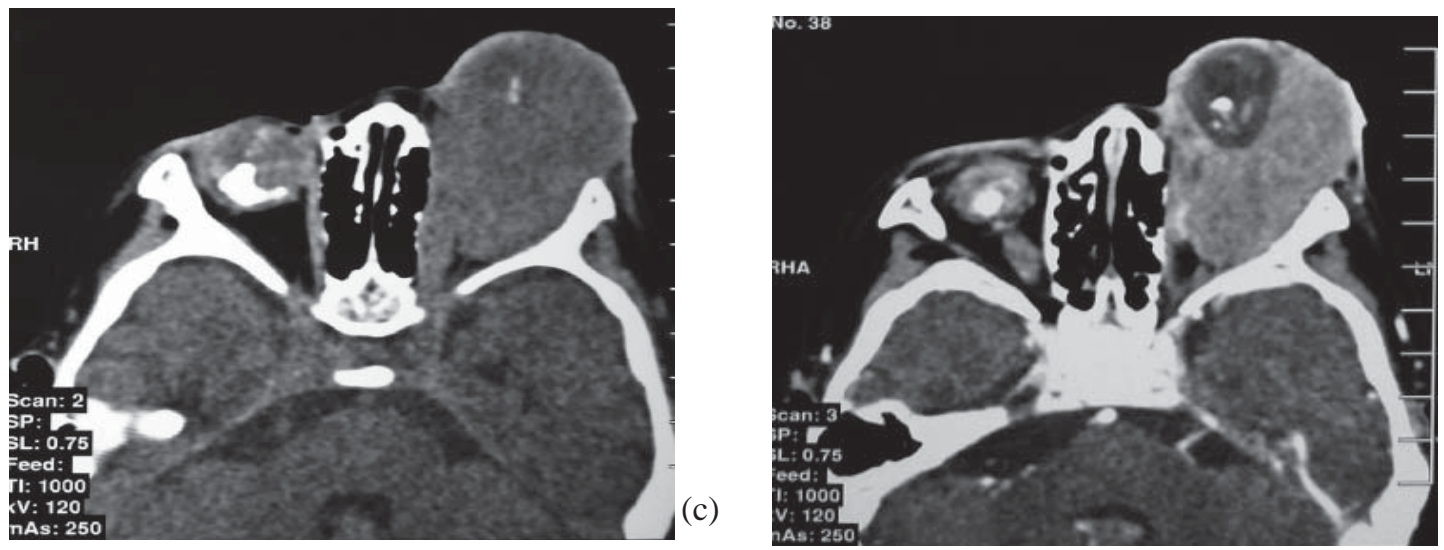

(d)

Figure 2. CT scan findings in grade II. (a) pre contrast; (b) post contrast showed no enhancement, no calcification; (c) pre contrast; (d) post contrast showed enhancement 


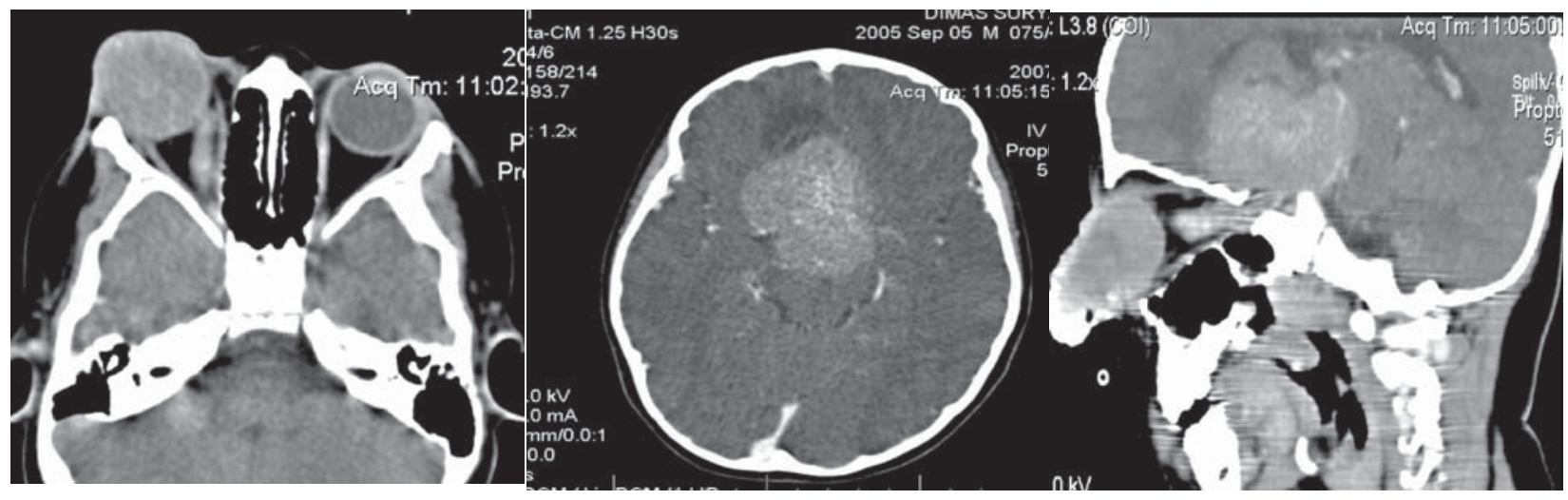

Figure 3. CT scan findings in Grade III. Enhancement, fine flecks calcification

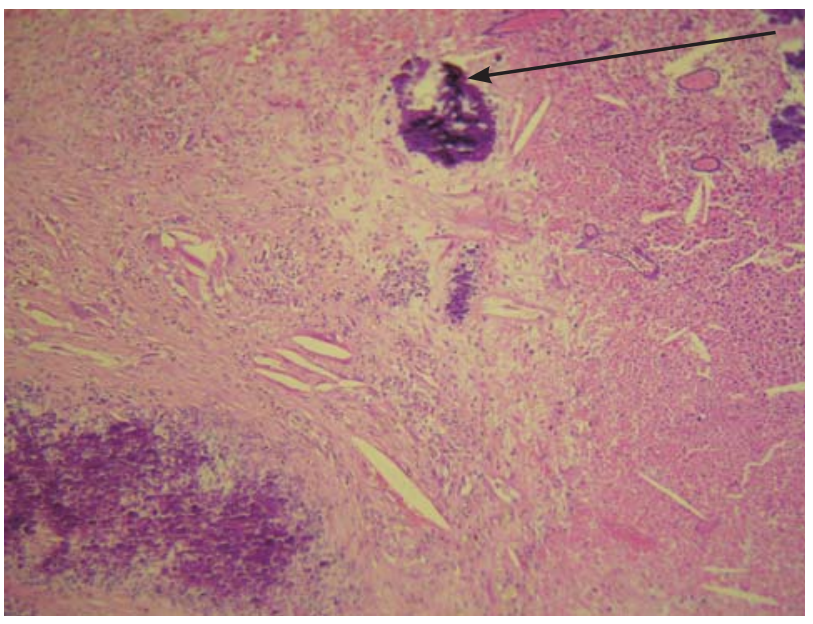

Figure 4. Calcification in hispathological specimen (arrow show the calcification)

\section{DISCUSSION}

Calcification is one of the important features for diagnosis of retinoblastoma, as $90-95 \%$ of the cases show calcification..$^{4-7}$ This study revealed calcification in $92 \%$ of patients. Different forms of calcification can be demonstrated, ranging froms fine, small calcification to large calcification with single or multiple form. ${ }^{4-6}$ In this study, 5 patients showed no calcification i.e. 3 patients in grade II, and 2 patients in grade III) (Table 1). Histopathologyevaluation, however, showedcalcification in all of grade I cases. Histopathologically, calcification is identified in the necrotic area of the tumor (Figure 4). ${ }^{8}$ As a sensitive method to evaluate calcification, CT scan has limitation in detecting very fine calcification. In this study we were not able to confirm the results in group III pathologically, since no surgery has been done in this group. It had been reported that calcification could not occur in a very fast growing tumor, as found in undifferentiated retinoblastoma. ${ }^{6,9}$

This study demonstrated that all calcification is located in bulbus oculi. No extraocular calcification was found, although the tumor had extended retrobulbar or even intracranial. This is in accordance with the results reported by Olivecrona et $\mathrm{al}^{10}{ }^{10}$ who found that only intraocular calcification was identified. Intraocular circulation is derived from terminal arteriole or end artery, whereas extraocular tissue has better vascularization. ${ }^{8,10}$ Danziger et $\mathrm{al}^{11}$ reported that calcification can occur in cases where the tumor is still limited in the bulbus oculi, so it was concluded that calcification is a good prognostic factor. The number of cases in Danziger study, ${ }^{11}$ however, was limited to 38 patients and the majority had intraocular tumor, and only $38 \%$ cases were extraocular. In our study, the majority (91\%) of cases were extraocular RB. In contrast to Danziger study, ${ }^{11}$ we found that calcification can be identified in either intraocular or exraocular tumor, indicating that calcification is not a good favourable prognostic factor of the tumor.

Leukocoria is the most common presenting symptom of $\mathrm{RB}$. This is the initial sign in more than $75 \%$ of cases. It is present as a white pupil reflex while it is relatively small and the location of tumor is at macula region. When the tumor arises at retinal periphery it may grow large before it presents leukocoria. ${ }^{4-6}$ Study comparison 
between clinical findings and grading of CT scan showed that patients with leukocoria without proptosis had extraocular extension (grade II) in $68 \%$ cases. This fact means that CT examination should be performed for all RB patients even though there are no sign of proptosis that can be interpreted as extraocular extension, since treatment of choice is completely different between intraocular and extraocular RB. ${ }^{12}$

Protosis is also a common presenting sign of RB in developing countries. Fourty one patient (64\%) in this study have proptotic eye. Among 41 patients with proptotic eye, CT scan showed intracranial extension in 14 patients (34\%). Intracranial metastasis in RB can occur by direct extension to the chiasma opticum as was show in $72 \%$ of our cases, hematogenous and cerebro spinal fluid (CSF) extension. ${ }^{7}$

Both patients with buphthalmus and red eyes were included in grade II. The CT scan revealed no calcification in patients with red eyes. Red eyes is a common manifestation of diffuse infiltrating RB. It is a frequent cause of misdiagnosis. Furher, CT diagnosis for diffuse infiltrating RB is a challenge as well, because it does not have calcification as the major sign of RB. ${ }^{9}$ Buphthalmus is associated with exophytic tumor growth. In exophytic retinoblastoma, the integrity of the nerve fibers is disrupted by retinal detachment. It makes easier for the invasion of tumor cells to the optic nerve. This study showed involvement of the optic nerve in buphthalmus patients.

Computed tomography examination with contrast is a routine procedure in all cases of tumors including RB. Using contrast media, the tumor margin can be better visualized to the vitreous. Contrast enhancement can visualize clearly both intraocular, as well as the extraocular tumors. If the tumors have invaded the sclera and lamina cribosa, extraocular growth has occurred. In our cases contrast enhancement was not associated with tumor extension into the extraocular, since the enhancement was also identified in the intraocular cases. Once the tumor grows beyond a diameter of $2 \mathrm{~mm}$, passive diffusion is no longer sufficient to support viability of tumor cells. Therefore angiogenic switch is occurred when the tumor grows beyond the occult stage. Higher vessel density can be predicted by CT scanning. Density measurement are directly proportional to the iodine concentration contained in the injected contrast media. ${ }^{13}$

Our study also showed that most of cases that were admitted to our clinic for CT examination were in advanced stage, which was $69 \%$ retro bulbar and 22\% intracranial, indicating that the goal of the treatments were mainly for life survival. Radiology examinations should, then, be done as soon as possible to prevent treatment delay and invasion into the brain.

In conclusion, diagnosis should be made as soon as possible, as the majority of RB cases admitted to our clinic were in advanced stage. Leukocoria presentation without proptotic eye can not exlude extraocular invasion. Intracranial invasion should be considered in proptotic RB patient. Calcification was not a favourable prognostic feature in retinoblastoma cases.

\section{REFERENCES}

1. Gatta G, Capocaccia R, Coleman MP, Ries GA, Berrino F. Childhood cancer survival in Europe and United states. Cancer. 2002; 95(8): 1767-72.

2. Yoo KH, Sohn WY, Sung KW, Jung HL, Koo HH, Oh SY et al. Chemoreduction followed by local therapy and adjuvant chemotherapy for advanced intraocular retinoblastoma. J Korean Med Sci. 2002;17: 817-22.

3. Departemen Anak divisi Hematoonkologi. Data insiden tumor anak. Jakarta : The Department; 2000.

4. Faerber EN, Poussaint TY. The orbit. In: Kuhn JP, Slovis TL, Haller J, eds. Caffey's pediatric diagnostic imaging. $10^{\text {th }}$ edition. USA: Mosby; 2004. p.414-5.

5. Mafee MF. Eye and orbit. In: Mafee MF, Valvassori GE, Becker M, eds. Imaging of the head and neck. $2^{\text {nd }}$ edition. Germany: Thieme Verlag; 2005. p.137-43.

6. Barkovich AJ. Intracranial, orbital, and neck masses of childhood. In: Barkovich AJ, ed. Pediatric neuroimaging. Fourth edition. USA: Lippincott Williams and Wilkins; 2005. p.618-20.

7. Aerts I, Lumbroso le Rovic L, Gauthier Villars M, Brisse H, Doz F, Desjardins L. Retinoblastoma. Orphanet Journal of Rare Diseases. 2006; 1: 31-40.

8. Wang SK. Intraocular tumor. In: Wang SK, Lee WR, eds. Ophthalmic pathology. USA:Blackwell; 2005. p.259-60.

9. Brisse HJ, Lumbroso le Rovic L, Freneanx PC, Validire P, Doz FP, Quintana EJ, et al. CT and MRI findings in diffuse infiltrative retinoblastoma. AJNR. 2001; 22: 499-504.

10. Olivecrona H, Agerberg AP, Huaman A. CT Diagnosis of retinoblastoma with histopathology correlations. Eur Radiol. 1994; 4:307-13.

11. Danziger A, Price HI. CT findings in retinoblastoma. AJR. 1979; 133: 783-5.

12. Bellaton E, Bertozzi AI, Behar C, Chastagner P, Brisse $\mathrm{H}$, Sainte-Rose C, et al. Neoadjuvant chemotherapy for extensive unilateral retinoblastoma. $\mathrm{Br} \mathrm{J}$ Ophthalmol. 2003;87:327-29.

13. Barrett T, Brechbiel M, Bernando M, Peter L, Choyke. MRI of tumor angiogenesis. Journal of MRI. 2007; 26:235-49. 